\title{
IMPLEMENTASI DELAPAN METODE KEPRAMUKAAN SEBAGAI BENTUK PENGUATAN PENDIDIKAN KARAKTER SISWA SEKOLAH DASAR
}

\author{
Ahmad Yasar Ramda dan Yoyon Suryono \\ Program Pascasarjana, Pendidikan Luar Sekolah, Universitas Negeri Yogyakarta \\ email:ahmadyasar9@gmail.com
}

\begin{abstract}
Abstrak
Tujuan penelitian ini adalah untuk mendeskripsikan implementasi 8 metode kepramukaan sebagai penguatan pendidikan karakter siswa sekolah dasar di Kecamatan Selong. Penelitian ini merupakan penelitian deskriptif kualitatif. Subjek dalam penelitian ini berjumlah 54 orang sebagai data primer, terdiri dari 3 orang kepala sekolah, 6 orang pembina putra dan putri, 45 orang siswa atau anggota pramuka penggalang SD. Data diperoleh melalui hasil wawancara, observasi, dan dokumentasi. Data dianalisis dengan menerapkan teknik analisis interaktif Miles dan Huberman. Kebenaran dan keabsahan data ditetapkan melalui teknik triangulasi sumber, metode, dan waktu. Hasil penelitian membuktikan bahwa implementasi delapan metode kepramukaan terdiri dari: mengamalkan kode kehormatan pramuka, memberikan bimbingan dan motivasi dari pembina, menyelenggarakan kegiatan secara berkelompok, menyelenggarakan kegiatan yang menarik dan menantang, melakukan aktivitas sambil belajar, menyelenggarakan kegiatan di alam terbuka, menerapkan sistem satuan terpisah, dan memberikan penghargaan tanda kecakapan. Pelaksanaan metode kepramukaan berpotensi sebagai sarana untuk menguatkan karakter siswa sekolah dasar.
\end{abstract}

Kata kunci: metode kepramukaan, pendidikan karakter, siswa sekolah dasar

\section{THE IMPLEMENTATION OFEIGHT SCOUTING METHODS IN REINFORCING ELEMENTARY STUDENTS' CHARACTER}

\begin{abstract}
This study was aimed at describing the implementation of 8 scouting methods as strengthening character education for elementary school students in Selong. This research was a qualitative descriptive study. The subjects were 54 people as primary data, consisting of 3 school principals, 6 male and female coaches, 45 students or members of elementary school scouts. The data were obtained through interviews, observation, and documentation. Then they were analyzed by applying the interactive analysis technique of Miles and Huberman. The correctness and validity of the data were determined through the triangulation technique of sources, methods, and time. The results show that the implementation of the eight scouting methods consists of: practicing the scouting honor code, providing guidance and motivation from the coach, organizing activities in groups, organizing interesting and challenging activities, carrying out activities while learning, holding activities in the open, implementing a separate unit system. , and giving awards a mark of proficiency. The implementation of the scouting method has the potential as a means of strengthening the character of elementary school students.
\end{abstract}

Keywords: scouting methods, character education, elementary students 


\section{PENDAHULUAN}

Pendidikan karakter sebagai salah satu visi pendidikan di Indonesia. Siswa tidak hanya dibekali ilmu pengetahuan, akan tetapi pengetahuan itu dapat diaktualisasikan ke dalam kehidupan sehari-hari. Bahkan penguatan pendidikan karakter di sekolah dasar menjadi prioritas utama dan mendapatkan porsi yang lebih banyak dibandingkan pengajaran pengetahuan. Karena gerakan terhadap penguatan karakter siswa menjadi bagian dari pondasi utama pendidikan. Hal ini tertuang dalam tujuan pendidikan nasional, yaitu:untuk mengembangkan potensi peserta didik, beriman dan bertakwa terhadap Tuhan Yang Maha Esa, membentuk karakter, berwawasan luas, kreatif, sehat, mandiri, demokratis, dan bertanggung jawab (Isdaryanti, Rachman, Sukestiyarno, Florentinus, \& Widodo, 2018).

Pendidikan karakter menjadi salah satu isu yang hangat diperbincangkan, ketika diberlakukan pendidikan karakter secara nasional, khususnya pendidikan tingkat sekolah dasar (Aeni, 2014). Pada tingkat pendidikan awal, siswa harus dibekali dengan pengatuhan tentang nilai-nilai yang baik untuk membentuk karakter anak sejak dini. Upayadalam mengembangkan manusia seutuhnya melalui pendidikan. Kualitas kemanusiaan yang berkaitan dengan perilaku merupakan hasil dari proses belajar (Suratmi \& Munhaji, 2015). Dewasa ini pendidikan karakter sangat diperlukan oleh generasi muda, karena maraknya fenomena sosial terutama pada penyimpangan-penyimpangan moral, etika, sistem nilai sosial, dan budaya bangsa (Afandi, 2011). Oleh karena itu, lulusan pendidikan diharapkan dapat membentuk karakter siswa (character building), sehingga mereka dapat ikut serta dalam pembangunan nasional di masa depan, namun tetap berlandaskan pada nilai-nilai moral atau akhlak yang baik (Marzuki \& Hapsari, 2015).

Pendidikan karakter dalam istilah lain dapat diartikan sebagai pendidikan moral, pendidikan budi pekerti, pendidikan nilai, dan pendidikan watak yang bertujuan untuk mengamalkan kebaikan dalam kehidupan sehari-hari (Cahyo, 2017). Implementasi pendidikan karakter di sekolah bertujuan untuk mengembangkan kemampuan siswa dalam memilih sesuatu yang baik, dijaga dan diaplikasikan dalam kehidupan mereka, serta dilakukan secara sadar dan berkelanjutan. Karena pendidikan sebagai sarana untuk mempromosikan perilaku dan sikap yang baik, menjaga nilai-nilai kebangsaan, menghargai keragaman dan perbedaan, serta kecenderungan untuk menghadapi dunia yang semakin kompetitif (Qoyyimah, 2016).

Sebagai tripusat pendidikan, lingkungan keluarga, sekolah, dan masyarakat sangat membantu proses pendidikan karakter, dengan cara mendukung satu sama lain sehingga menjadi kesatuan yang utuh. Implementasi pendidikan karakter menjadi tanggung jawab bersama dalam mencapai tujuan pendidikan, namun beban lingkungan sekolah lebih besar dalam menginternalisasikan pikiran (Wijayanti, 2018). Pembiasaan di sekolah melalui kegiatan yang positif sangat membantu anak, terutama melalui kegiatan-kegiatan ekstrakurikuler yang diorientasikan untuk membentuk perilaku, sikap, dan kepribadian anak (Yatmiko, Banowati, \& Suhandini, 2015).

Kegiatan-kegiatan positif tersebut dapat diaplikasikan melalui kegiatan intrakurikuler, kokurikuler, dan ekstrakurikuler dengan membangun kolaborasi dari tripusat pendidikan. Selain itu, penguatan pendidikan karakter siswa di sekolah dapat dilakukan melalui tiga cara, yakni: pendidikan karakter yang terintegrasi 
dengan semua mata pelajaran sehingga aktivitas belajar dan mengajar sebagai pendukung penguatan pendidikan karakter; pendidikan karakter melalui kegiatan ekstrakurikuler dan intrakurikuler; dan pendidikan karakter yang dilaksanakan melalui program sekolah yang melibatkan warga sekolah (Dit. PSMP Kemdiknas, 2010).

Hasil penelitian Sukoyo (2017) menemukan bahwa perbedaan karakter siswa setelah diberikan pembelajaran menggunakan media lagu-lagu berbahasa Jawa menunjukkan hasil yang lebih positif dalam pembiasaan karakter disiplin, mandiri, kerja keras, religius, dan peduli lingkungan. Nilai karakter yang sering mengalami peningkatan merupakan nilai karakter peduli terhadap lingkungan. Hal ini didorong karena guru sebagai role model dalam membiasakan anak di sekolah untuk selalu peduli terhadap lingkungan sejak awal anak masuk PAUD. Wulandari, Wijayanti, dan Saliman. (2019) menjelaskan bahwa untuk mengembangkan nilai karakter anak melalui knowing (pengetahuan), acting (melakukan), dan menjadi habit (kebiasaan), karakter bukan hanya sekedar pengetahuan, akan tetapi tercermin dalam tindakan nyata secara berkesinambungan baik dalam lingkungan keluarga, sekolah maupun masyarakat.

Penguatan pendidikan karakter dalam lingkungan sekolah merupakan tanggung jawab bersama dengan melaksanakan ketegasan terkait dengan aturan sekolah dalam membentuk karakter warga sekolah terutama siswa (Agustina, 2018). Budaya sekolah yang disiplin, kerjasama, tanggung jawab dan saling menghormati mengakibatkan suasana yang kondusif untuk meningkatkan kenyamanan dan semangat bekerja. Selain itu, pembentukan karakter kepada siswa dapat memberikan pengaruh yang positif terhadap prestasi belajar mereka, terutama nilai karakter disiplin memberikan sumbangsih yang paling besar (Irjanti \& Setiawati, 2018).

Berdasarkan data dari Komisi Perlindungan Anak Indonesia pada semester pertama tahun 2018 telah menangani sebanyak 1.885 kasus, dan kasus Anak Berhadapan Hukum (ABH) terdapat ada 504 kasus di antaranya: pelaku mencuri sebanyak 23,9\%; narkoba sebanyak 17,8\%; dan asusila sebanyak $13,2 \%$ (detik. com, 2018). Ada beberapa faktor yang menyebabkan dekadensi moral ini terjadi terhadap anak yakni: pengaruh teknologi informasi, filter informasi yang kurang, pergaulan bebas, lemahnya pengawasan orang tua, dan lemahnya pengawasan dari lembaga pendidikan (Cahyo, 2017). Pendidikan sebagai alternatif yang bersifat preventif untuk mengatasi masalah budaya dan karakter bangsa yang banyak dikemukakan (Ambarini, 2017).

Dukungan dari pemerintah daerah Kabupaten Lombok Timur terhadap program penguatan pendidikan karakter telah dilaksanakan sejak tahun 2017. Akan tetapi, penyelenggaraan program pendidikan di sekolah tidak berbanding lurus dengan apa yang diharapkan oleh pemerintah daerah. Artinya, terdapat diskomunikasi bagaimana menyusun dan melaksanakan program penguatan pendidikan karakter yang lebih baik. Di sisi lain, guru merasa dibebankan dengan banyaknya administrasi yang harus dikerjakan, sehingga mengesampingkan peran utama seorang guru untukmemberikan ilmu pengetahuan dan membentuk karakter siswa. Akibtanya, pendidikan karakter masih bersifat administratif dan tidak dapat diinternalisasi serta diaktualisasikan oleh siswa dalam kehidupan sehari-hari.

Persoalan lain yang dihadapi oleh guru adalah kurangnya kemampuan untuk mendesain pembelajaran yang menarik agar tujuan pembelajaran dapat tercapai 
dengan optimal. Minimnya keterlibatan semua pihak dalam penyelenggaraan penguatan pendidikan karakter yang menghambat proses pembentukan karakter siswa. Karena penguatan pendidikan karakter hanya dilaksanakan di lingkungan sekolah dan tidak dilakukan secara berkelanjutan (sustainable) di lingkungan keluarga maupun masyarakat. Semua aspek pendidikan diharapkan sebagai ladang untuk aktivitas atau kegiatan mendidik yang dilakukan melalui metode menarik dan menantang menjadi salah satu alternatif dalam mengasah potensi siswa dan mengatasi masalah-masalah dekadensi moral generasi muda.

Kegiatan ekstrakurikuler sebagai sarana yang tepat dalam penguatan karakter siswa di sekolah. Hasil penelitian Marzuki dan Hapsari (2015) menemukan bahwa kegiatan kepramukaan di MAN 1 Yogyakarta dapat membentuk karakter siswa melalui peran pembina dan dukungan fasilitas dengan kegiatan yang modern, menarik, dan menantang. Metode kepramukaan antara lain: pengamalan kode kehormatan pramuka, berkelompok, berkerja sama dan berkompetisi, dilakukan di tempat alam terbuka, penghargaan, belajar sambil melakukan, dan satuan terpisah. Kegiatan kepramukaan sebagai sarana yang baik dalam membentuk karakter tanggung jawab siswa di SMP Negeri 2 Windusari Magelang (Woro \& Marzuki, 2016). Hal ini dilakukan melalui pemberian nasihat, sanksi, keteladanan, pemberian penghargaan, dan pencapaian SKU dan SKK. Dukungan dari pembina, pihak sekolah, dan orang tua sebagai faktor pendukung pembentukan karakter tanggung jawab siswa.

Beberapa hasil penelitian di atas menggambarkan ekstrakurikuler pramuka dapat dijadikan sebagai kegiatan pendukung kegiatan akademik siswa, ter- utama dalam penguatan karakternya. Keberhasilan dalam penguatan pendidikan karakter siswa dibutuhkan proses atau kegiatan yang positif dan dilakukan secara kontinyu untuk memberikan efek yang optimal (Solihati, Hikmat, Rahman, \& Hidayatullah, 2019). Oleh karena itu, kegiatan ekstrakurikuler pramuka dilaksanakan dengan cara terintegrasi antara pembelajaran di sekolah dengan metode yang kreatif, inovatif, dan menyenangkan. Penelitian ini berupaya untuk menemukan dan mendeskripsikan implementasi delapan metode kepramukaan sebagai bentuk penguatan pendidikan karakter siswa sekolah dasar.

\section{METODE}

Penelitian ini menggunakan pendekatan kualitiatif. Lokasi penelitian dilaksanakan di SDN 3 Pancor, MI Hamzanwadi 1 Pancor, dan SDN 2 Selong yang berada di Kecamatan Selong, Kabupaten Lombok Timur. Penentuan tiga sekolah tersebut didasarkan pada keaktifan ekstrakurikuler pramuka di satuan pendidikan di Kecamatan Selong. Subjek dalam penelitian ini berjumlah 54 orang sebagai data primer, terdiri atas 3 orang kepala sekolah, 6 orang pembina putra dan putri, 45 orang siswa atau anggota pramuka penggalang SD. Sedangkan hasil penelitian terdahulu dan dokumen pendukung lainnya dijadikan sebagai sumber data sekunder. Penentuan subjek penelitian dengan menetapkan kriteria khusus untuk mengumpulkan informasi sesuai dengan tujuan penelitian.

Data diperoleh menggunakan teknik wawancara dengan kepala sekolah, guru, pembina, dan siswa; observasi kondisi sekolah dan kegiatan kepramukaan; dan dokumentasi mengenai data sekolah, program ekstrakurikuler pramuka, serta prestasi dan jumlah anggota pramuka. Kebenaran dan keabsahan data ditetapkan 
melalui teknik triangulasi sumber, metode, dan waktu. Hal ini dilakukan untuk membandingkan dan membuktikan kebenaran data yang didapatkan dengan cara pengecekan (recheck).

Data dianalisis dengan menerapkan model interaktif (interactive model) yang mengikuti format dari Miles dan Huberman (1992) yang meliputi tiga tahapan yaitu: reduksi data, penyajian data, dan penarikan kesimpulan. Tiga tahapan tersebut diawali dengan reduksi data untuk mem-filter dan menyederhanakan data yang diperoleh melalui teknik wawancara dan observasi; penyajian data (display data) dalam bentuk deskripsi tentang hasil wawancara, observasi, dan dokumentasi implementasi metode kepramukaan sebagai bentuk penguatan pendidikan karakter siswa sekolah dasar; dan pada tahap akhir penarikan kesimpulan berdasarkan sumber data di lapangan yang diperoleh dari data primer dan sekunder.

\section{HASIL PENELITIAN DAN PEMBAHASAN}

Berdasarkan Undang-undang Nomor 12 Tahun 2010 tentang Gerakan Pramuka dan Permendikbud RI Nomor 63 Tahun 2014 tentang Pendidikan Kepramukaan, dinyatakan kegiatan ekstrakurikuler pramuka menjadi wajib untuk anak di tingkat dasar dan menengah karena pendidikan kepramukaan sebagai sarana untuk membentuk kepribadian, keterampilan, dan akhlak mulia melalui kegiatan-kegiatan yang menarik dan menantang. Dalam penyelenggaraan kepramukaan harus disesuaikan dengan pedoman pelaksanaan berdasarkan keputusan dari Kwarnas Gerakan Pramuka Nomor 220 Tahun 2007. Namun, dalam penyelenggaraan dikembangkan dan disesuaikan dengan kebutuhan dari gugus depan masing-masing.

Pembina pramuka di SDN 3 Pancor terdapat satu orang pembina gugus depan, dua orang pembina satuan, dan dua orang pembantu pembina. Di MI Hamzanwadi 1 Pancor memiliki satu orang pembina gugus depan, dua orang pembina satuan, dan empat orang pembantu pembina. Di SDN 2 Selong terdapat satu orang pembina gugus depan, dan dua orang pembina satuan. Keterlibatan langsung dari pembina dalam setiap kegiatan sangat penting untuk mencapai tujuan terselenggaranya kegiatan kepramukaan dapat terwujud. Kemudian gugus depan merupakan suatu kesatuan organik yang memiliki tujuan untuk menghimpun anggota pramuka dan sebagai pangkalan untuk dapat berkomunikasi, edukasi, dan berkolaborasi dengan anggota muda.

Pendataan nomor gugus depan dalam satu pangkalan ditentukan oleh Kwartir Cabang Lombok Timur. Berdasarkan pendataan tersebut ditetapkan nomor gugus depan untuk SDN 3 Pancor yaitu 13.017-13.018, MI Hamzanwadi 1 Pancor yaitu 13.123-13.124, dan SDN 2 Selong yaitu 13.003-13.004. Anggota pramuka di sekolah dasar terbagi menjadi dua golongan berdasarkan umur dan pencapaiannya, yaitu anggota pramuka golongan siaga dan golongan penggalang. Pada Tahun Ajaran 2018-2019 di SDN 3 Pancor terdaftar sejumlah 92 anggota, terdiri atas 42 orang anggota golongan siaga dan 50 orang anggota golongan penggalang. Di MI Hamzanwadi 1 Pancor terdaftar sejumlah 73 anggota, terdiri atas 32 orang anggota golongan siaga dan 41 orang anggota golongan penggalang. Di SDN 2 Selong terdaftar sejumlah 60 orang anggota, terdiri atas 25 anggota golongan siaga dan 35 orang anggota golongan penggalang.

Penyelenggaraan ekstrakurikuler pramuka di SDN 3 Pancor, MI Hamzanwadi 1 Pancor, dan SDN 2 Selong sudah dilaksanakan dengan baik. Hal ini dibuktikan dengan prestasi yang telah didapatkan, 
baik dalam lomba tingkat kwartir ranting, cabang, maupun daerah. Prestasi yang diperoleh karena kerja keras dari semua yang terlibat dalam penyelanggaraan pramuka, mulai dari peran kwartir cabang Lombok Timur, majelis pembimbing gugus depan, pembina putra dan putri, sampai pada peran anggota pramuka masing-masing gugus depan. Keberhasilan penyelenggaraan kegiatan kepramukaan dalam gugus depan dipengaruhi oleh faktor keselarasan pelaksanaan kegiatan dengan penyusunan program yang telah dibuat.

Penyusunan program kegiatan ekstrakurikuler pramuka di SDN 3 Pancor dilakukan satu kali dalam enam bulan. Di MI Hamzanwadi 1 Pancor dan SDN 2 Selong dilakukan satu kali dalam satu tahun. Penyusunan program terbagi menjadi tiga bagian, yaitu program jangka pendek, menengah, dan panjang. Pembagian program tetap berpedoman pada prinsip dasar kepramukaan dan isi SKU atau syarat-syarat kecakapan umum golongan penggalang.

Kegiatan kepramukaan yang dilaksanakan di SDN 3 Pancor, di antaranya: pelantikan anggota baru gerakan pramuka yang diikuti oleh siswa yang berusia 7-10 tahun (pramuka siaga), dan 1112 tahun (pramuka penggalang) SD, yang dilaksanakan dalam satu tahun sekali; pengisian SKU dan pelantikan kenaikan tingkat wajib diikuti oleh anggota gerakan pramuka di SDN 3 Pancor, yang dilaksanakan dalam enam bulan sekali;kegiatan perkemahan Jumat, Sabtu, dan Minggu (perjusami) yakni kegiatan kemah yang dilakukan selama tiga hari di lingkungan sekolah, seperti: latihan baris-berbaris, pendirian tenda, semaphore, kegiatan keagamaan, upacara api unggun, penjelajahan, pentas seni, dan kegiatan menarik lainnya; anggota aktif mengikuti latihan gabungan (latgab) dan perlombaan antara gugus depan, kwartir ranting dan cabang; kegiatan kemah bakti dan apresiasi anggota pramuka; kegiatan latihan rutin sekali dalam satu minggu yang dilaksanakan setiap hari Kamis pukul 15.30-17.30 WITA; dan kegiatan gladi pinru (pimpinan regu) dan latihan khusus untuk anggota inti yang akan dipersiapkan untuk mengikuti perlombaan.

MI Hamzanwadi 1 Pancor merupakan salah satu Madrasah Ibtidaiyah percontohan di Kecamatan Selong karena prestasinya terutama dalam lomba pramuka. Dibalik prestasinya yang gemilang tersebut, terdapat beberapa program yang telah disusun di antaranya: penerimaan atau pengukuhan anggota golongan siaga menjadi anggota golongan penggalang yang dilaksanakan sekali dalam satu tahun; perkemahan Sabtu dan Minggu (persami) dirangkaikan dengan evaluasi materi yang telah dilaksanakan selama enam bulan, biasanya persami dilaksanakan pada saat siswa libur semester atau kemahan hari jadi gerakan pramuka; kegiatan peduli lingkungan dengan melakukan bersihbersih atau zero waste di lingkungan Yayasan Pendidikan Hamzanwadi NW Lombok Timur sebagai kontribusi untuk menyukseskan world clean up day 2019; ikut serta dalam latihan gabungan (latgab) dan perlombaan (LT I, LT II, dan LT III), dan lomba yang dilaksanakan oleh Racana (Temu Aksi Galang Penegak (TAKSI), Kemah Silaturrahmi (KSLP3), Lintas Galang Ridhol Walidain (LIGARDA), dan Nurul Harmain Scout Camp Competition (NHSCC); latihan rutin yang dilaksanakan pada hari Jumat pukul 15.30-17.30 WITA; dan latihan khusus pada hari Sabtu dan Minggu sore bagi anggota regu inti yang telah diseleksi sebagai perwakilan mengikuti lomba.

Kegiatan kepramukaan yang diprogramkan di SDN 2 Selong, yaitu: kegiatan perkemahan Sabtu dan Minggu 
(persami) yang dilaksanakan setiap satu tahun sekali pada tahun pelajaran baru dan dirangkaikan dengan pengukuhan anggota gerakan pramuka golongan penggalang; kegiatan latihan rutin yang dilakukan setiap hari Sabtu pukul 15.30-17.30 WITA yang wajib diikuti oleh seluruh anggota pramuka golongan siaga dan golongan penggalang;kegiatan latihan khusus bagi regu yang terpilih untuk mewakili gudep dalam kegiatan lomba, yang dilaksanakan setiap hari Sabtu pukul 13.00-15.00 WITA; kegiatan kemah uji kenaikan golongan dan tingkat yang dilaksanakan pada akhir semester, kegiatan ini juga dilakukan dengan penjelajahan sebelum anggota pramuka dinyatakan lulus dan berhak mendapatkan Tanda Kecakapan Umum (TKU) penggalang ramu, rakit, dan terap.

Penyelenggaraan ekstrakurikuler pramuka merupakan kegiatan wajib di SDN 3 Pancor, MI Hamzanwadi 1 Pancor, dan SDN 2 Selong. Kurikulum yang dikembangkan oleh ketiga sekolah tersebut menggunakan K13. Peran kegiatan pramuka dapat mendorong kompetensi, sikap, karakter, serta mendukung kegiatan kurikuler siswa yang dilaksanakan dalam proses pembelajaran di sekolah. Implementasi K13 dalam pembelajaran di kelas dilaksanakan menggunakan metode kepramukaan. Kegiatan kepramukaan dilaksanakan sesuai dengan kebutuhan anggota gerakan pramuka, tetap berpedoman pada prinsip dasar pramuka, dan kompetensi yang harus dicapai anggota pramuka dalam pedoman syarat-syarat kecakapan umum.

Metode kepramukaan yang dilaksanakan di SDN 3 Pancor, MI Hamzanwadi 1 Pancor, dan SDN 2 Selong telah dikembangkan sehingga kegiatan semakin menarik, menantang, dan meningkatkan rasa keingintahuan anggota pramuka. Metode yang dikembangkan dalam setiap kegiatan digunakan delapan mteode kepramukaan. Pertama, mengamalkan kode kehormatan pramuka tertuang dalam Tri Satya dan Dasa Dharma pramuka yang diucapkan pada saat pelantikan sebagai janji yang harus dijalankan atau diterapkan dalam kehidupan sehari-hari baik dalam lingkungan sekolah, rumah, maupun masyarakat, sehingga perilaku anggota sesuai dengan ikrar yang telah diucapkan. Selain itu, membina kesadaran beragama, peduli lingkungan, menempati janji, dan bersikap jujur dalam setiap kegiatan.

Kedua, bimbingan, dorongan, dan dukungan dari pembina pramuka dalam setiap kegiatan. Keberadaan orang dewasa sebagai orang yang digugu, ditiru, dan sebagai orang yang memberikan batasan kepada siswa. Karena kegiatan pramuka dilakukan di alam terbuka, dibutuhkan keberadaan dari orang dewasa untuk mencegah hal-hal yang tidak diiginkan. Keberadaan orang dewasa, seperti: kepala sekolah, guru, dan pembina terlibat aktif ketika perlombaan dengan menasihati, memotivasi, mengawasi, dan mengevaluasi pada saat sebelum, sesaat, dan sesudah kegiatan sebagai bentuk keterlibatan orang dewasa dalam kegiatan pramuka.

Ketiga, kegiatan dilakukan secara berkelompok, berkerja sama, dan siap berkompetisi. Membagi anggota pramuka ke dalam sistem kelompok atau regu yang memiliki tujuan untuk meningkatkan semangat kerjasama antara anggota pramuka. Setiap regu terdapat pimpinan regu yang memudahkan pembina membangun koordinasi antara anggota pramuka dalam regu dengan tugas yang diberikan, sehingga dapat diselesaikan dengan cepat dan lebih baik. Melalui sistem regu juga dapat meningkatkan semangat berkompetisi anggota dan setiap regu, dengan melakukan kerja keras agar mendapatkan hasil yang lebih maksimal. 
Keempat, pelaksanaan kegiatan dilakukan secara menarik, menantang,dan kegiatan mengadung nilai pendidikan berdasarkan perkembangan rohani dan jasmani anggota. Kegiatan dilaksanakan memberikan rasa senang dan antusias untuk mengikuti kegiatan tanpa ada unsur paksaan. Dengan pendekatan baru, melalui kegiatan pentas seni dan budaya, penjelajahan, dan memainkan permainan tradisional dapat meningkatkan motivasi belajar anggota muda.

Kelima, kegiatan yang dilakukan memiliki karakteristik learning by doing, yakni setiap kegiatan materi yang disampaikan kemudian dilanjutkan dengan praktik, contohnya: materi baris-berbaris, sandi, semaphore, pionering/tali-temali, morse, PPPK dan kesehatan. Tujuan learning by doing untuk memberikan kemudahan kepada anggota pramuka dalam memahami materi yang disampaikan, memiliki rasa keingintahuan anggota dengan hal-hal yang baru, dan memberikan keterampilan serta pengalaman.

Keenam, kegiatan pramuka miliki ciri khas tersendiri, yaitu hampir ratarata kegiatan dilakukan di alam terbuka karena alam merupakan salah satu sumber belajar yang dapat dimanfaatkan, karena setiap tempat adalah sumber belajar untuk anggota. Selain itu, kegiatan seperti: kemah bakti pramuka, perkemahan SabtuMinggu (persami), dan kemah pelantikan dapat memberikan suasana belajar baru dan mengajarkan anggota untuk hidup sederhana, apa adanya, dan mandiri di alam bebas.

Ketujuh, menggunakan satuan terpisah antara kelompok (regu) putra dan putri, yang memiliki tujuan untuk memudahkan kegiatan yang disesuaikan dengan jenis kelamin, karena kegiatan dan kebutuhan antara anggota putra dan putri berbeda. Dalam administrasi gerakan pramuka telah diatur, mulai dari penomoran gugus depan, sampai pada pembina satuan menerapkan satuan terpisah. Namun, tidak menutup kemungkinan antara pembina putra dan putri dapat melakukan kerjasama dalam kegiatan latihan dan perlombaan, begitu juga antara anggota regu putra dan regu putri. Pada umumnya, pembagian anggota pramuka golongan penggalang di lokasi penelitian membagi menjadi dua regu, yaitu anggota regu umum dan regu khusus/ inti. Regu umum merupakan seluruh anggota muda yang ada di gugus depan tersebut yang terbagi ke dalam beberapa kelompok. Sedangkan regu khusus/inti adalah regu atau kelompok yang telah diseleksi menjadi perwakilan gugus depan untuk mengikuti perlombaan atau latihan gabungan. Pemilihan regu khusus/inti berdasarkan keatifan anggota regu dan pencapaian hasil maksimal dalam setiap latihan.

Kedelapan, pemberian penghargaan berupa tanda kecakapan (SKU dan SKK), setiap anggota pramuka diharuskan mengisi SKU dan mengikuti ujian SKK. Tanda kecakapan diberikan kepada nggota muda sebagai simbol bahwa anggota telah menguasai materi serta segala bentuk keterampilan-keterampilan yang diujikan. Anggota pramuka yang mengikuti ujian adalah anggota yang mempunyai minat yang tinggi dalam kegiatan pramuka, karena harus mengikuti serangkaian proses, mulai dari pengisian dan ujian, sampai pada proses pelantikan dan penyematan.

Pendidikan pramuka merupakan sebagai sarana yang tepat sebagai bentuk penguatan pendidikan karakter, kepribadian, dan pengamalan nilai-nilai pramuka dalam kehidupan sehari-hari bagi anggota. Keberadaan kegiatan pramuka dalam satuan pendidikan untuk mendukung intrakurikuler dan kokurikuler, serta mendukung pengembangan pendidikan 
karakter di sekolah dengan proses elaborasi visi dan misi sekolah dan dilaksanakan melalui aktivitas intrakurikuler dan ekstrakurikuler (Murdiono, Miftahuddin, \& Kuncorowati, 2017). Dalam mencapai tujuan tersebut, kegiatan dilaksanakan melalui delapan motode kepramukaan, yaitu dengan mengamalkan kode kehormatan, kegiatan belajar sambil melakukan, kegiatan (berkelompok, berkerja sama, dan berkompetisi), kegiatan yang didesain secara menarik dan menantang, kegiatan yang dilakukan di alam terbuka, orang dewasa memberikan bimbingan, dorongan, dan dukungan, pemberian pengahargaan tanda kecakapan, sertasistem satuan terpisah (putra dan putri). Metode dirancang untuk memberikan pengalaman belajar, meningkatkan rasa ingin tahu siswa, serta mencapai tujuan tertentu. Implementasi delapan metode kepramukaan tersebut berpotensi sebagai sarana menguatkannilainilai karakter, seperti: religius, disiplin, tanggung jawab, jujur, memiliki rasa ingin tahu, kreatif, mandiri, demokratis, toleransi, komunikatif, cinta tanah air, peduli lingkungan, peduli sosial, menghargai prestasi, dan kerja keras. Hal ini dapat dilihat dari Tabel 1.

Sekolah menyadari bahwa keberadaan ekstrakurikuler pramuka sebagai tempat untuk mendukung penguatanpendidikan karakter siswa. Keberadaan kepala sekolah, guru, dan pembina sangat memberikan dampak positif terhadap semangat siswa untuk mengikuti kegiatan pramuka. Disisi lain, kegiatan pramuka disesuaikan dengan materi pelajaran siswa dapatkan di sekolah, sehingga terdapat integrasi antara mata pelajaran dengankegiatan kepramukaan. Secara teori, siswa mendapatkannya dari guru mata pelajaran, sedangkan secara praktik dilaksanakan melalui kegiatan pramuka. Implementasi metode leraning by doing dapat memberikan pengetahuan dan pengalaman belajar, terutama ditekankan untuk membentuk karakter siswa. Hal ini sejalan dengan tujuan dari K13 untuk mengupayakan terbentuknya sikap dan perilaku (moral) siswa, meskipun ada beberapa aspek lain juga diharapkan, antara lain: keterampilan, pengetahuan, sosial, dan spiritual. Namun, pembentukan karakter siswa memiliki kedudukan yang paling utama untuk kesuksesan siswa di masa depan. Salah satu strategi yang dapat dimanfaatkan oleh sekolah adalah mengoptimalkankegiatan-kegiatan yang positif, salah satunya kegiatan kepramukaan. Kegiatan ekstrakurikuler pramuka menjadi wajib pada K13, sehingga proses pembelajaran di sekolah diselenggarakan dengan menggunakan metode kepramukaan (Nailiyah, Dayati, \& Desyanty, 2018).

Siswa dihadapkan dengan persoalan yang kompleks di masa yang akan datang, seperti dekadensi moral, westernisasi budaya, dan generasi muda kehilangan jati diri sebagai bangsa Indonesia. Salin itu, revolusi ilmu pengetahuan, informasi, interdependensi antara anggota dan kelompok masyarakat akan menjadi tantangan di masa yang akan datang sehingga dalam keadaan ini masyarakat akan mengalami metamorfosis menuju masyarakat terbuka/open society (Raharjo, 2010). Salah satu strategi untuk mengantisipasi persoalan tersebut adalah menguatkan peran pendidikan, terutama dalam penguatan pendidikan karakter. Hal ini menunjukkan pendidikan karakter melalui aktivitas intrakurikuler, kokurikuler, dan ekstrakurikuler masih tetap dibutuhkan untuk dilaksanakan secara holistik dan serentak berbasis pada pengembangan budaya sekolah.

Salah satu aktivitas positif yang dapat diupayakan dalam membentuk karakter kepada siswa sekolah dasar adalah dengan mengoptimalkan program-program 
Tabel 1

Implementasi Metode Kepramukaan dan Penguatan Nilai-nilai Karakter Siswa

\begin{tabular}{|c|c|c|c|}
\hline No & $\begin{array}{c}\text { Metode } \\
\text { Kepramukaan }\end{array}$ & Deskripsi Kegiatan & Nilai Karakter \\
\hline 1 & $\begin{array}{l}\text { Mengamalkan } \\
\text { kode kehormatan } \\
\text { pramuka }\end{array}$ & $\begin{array}{l}\text { - Pengamalan "Tri Satya dan Dasa Dharma } \\
\text { Pramuka" } \\
\text { - Mengembangkan perilaku baik di } \\
\text { lingkungan sekolah, rumah, maupun } \\
\text { masyarakat } \\
\text { - Membina kesadaran beragama, peduli } \\
\text { lingkungan, menempati janji, dan } \\
\text { bersikap jujur dalam setiap kegiatan }\end{array}$ & $\begin{array}{l}\text { Religius, disiplin, } \\
\text { tanggung jawab, dan } \\
\text { jujur }\end{array}$ \\
\hline 2 & $\begin{array}{l}\text { Kegiatan belajar } \\
\text { sambil melakukan }\end{array}$ & $\begin{array}{l}\text { - Mengasah rasa keingintahuan anak } \\
\text { dengan hal-hal baru } \\
\text { - Pendidikan keterampilan dan pengalaman }\end{array}$ & $\begin{array}{l}\text { Memiliki rasa ingin } \\
\text { tahu, kreatif, dan } \\
\text { kerja keras }\end{array}$ \\
\hline 3 & $\begin{array}{l}\text { Kegiatan } \\
\text { berkelompok, } \\
\text { berkerjasama, dan } \\
\text { berkompetisi }\end{array}$ & $\begin{array}{l}\text { - Membagi anggota pramuka ke dalam } \\
\text { kelompok (regu) } \\
\text { - Lomba tingkat (gugus depan, ranting, } \\
\text { cabang, daerah, dan nasional) }\end{array}$ & $\begin{array}{l}\text { Demokratis, } \\
\text { tanggung jawab, } \\
\text { toleransi, dan } \\
\text { komunikatif }\end{array}$ \\
\hline 4 & $\begin{array}{l}\text { Kegiatan yang } \\
\text { menarik dan } \\
\text { menantang }\end{array}$ & $\begin{array}{l}\text { - } \quad \text { Kegiatan pentas seni dan budaya } \\
\text { - } \quad \text { Penjelajahan dengan sistem pos } \\
\text { - Memainkan segala bentuk permainan, } \\
\text { termasuk permainan tradisional }\end{array}$ & $\begin{array}{l}\text { Kreatif, mandiri, } \\
\text { rasa ingin tahu, cinta } \\
\text { tanah air, dan kerja } \\
\text { keras }\end{array}$ \\
\hline 5 & $\begin{array}{l}\text { Kegiatan di alam } \\
\text { terbuka }\end{array}$ & $\begin{array}{ll}\text { - } & \text { Kemah bakti pramuka } \\
\text { - } & \text { Perkemahan Sabtu-Minggu (persami) } \\
\text { - } & \text { Kemah penerimaan dan pelantikan anggota } \\
& \text { baru }\end{array}$ & $\begin{array}{l}\text { Religius, peduli } \\
\text { lingkungan, peduli } \\
\text { sosial, mandiri, dan } \\
\text { menghargai prestasi }\end{array}$ \\
\hline 6 & $\begin{array}{l}\text { Memberikan } \\
\text { bimbingan, } \\
\text { dorongan, dan } \\
\text { dukungan }\end{array}$ & $\begin{array}{l}\text { Kepala sekolah, guru, dan pembina } \\
\text { terlibat aktif dalam kegiatan perlombaan, } \\
\text { serta memberikannasihat dan motivasi } \\
\text { anggota } \\
\text { - Pengawasan dan evaluasi pada saat } \\
\text { sebelum, sesaat, dan sesudah kegiatan }\end{array}$ & $\begin{array}{l}\text { Jujur, disiplin, dan } \\
\text { bertanggungjawab }\end{array}$ \\
\hline 7 & $\begin{array}{l}\text { Pemberian } \\
\text { pengahargaa tanda } \\
\text { kecakapan }\end{array}$ & 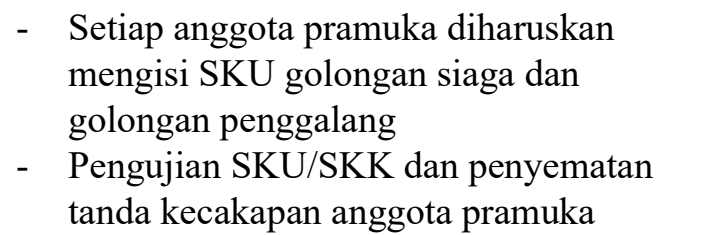 & $\begin{array}{l}\text { Menghargai prestasi, } \\
\text { kerja keras, mandiri, } \\
\text { dan disiplin }\end{array}$ \\
\hline 8 & $\begin{array}{l}\text { Satuan terpisah } \\
\text { (putra dan putri) }\end{array}$ & $\begin{array}{l}\text { - Administrasi, nomor gugus depan, dan } \\
\text { pembina satuan menerapkan satuan } \\
\text { terpisah. } \\
\text { - } \\
\text { Kegiatan disesuaikan dengan jenis } \\
\text { kelamin antara anggota putra dan putri }\end{array}$ & $\begin{array}{l}\text { Komunikatif, } \\
\text { mandiri, dan } \\
\text { tanggung jawab }\end{array}$ \\
\hline
\end{tabular}


kepramukaan yang disusun berdasarkan kebutuhan siswa dan budaya sekolah. Penyusunan program kegiatan kepramukaan disusun bersama dengan melibatkan kepala sekolah, pembina, komite, dan wali murid. Hal ini dilakukan untuk memudahkan semua aspek ikut terlibat dan bertanggung jawab dalam kegiatan kepramukaan di sekolah. Keterlibatan warga sekolah, keluarga dan masyarakat memberikan dampak pada pembiasaan karakter baik yang dapat dilakukan secara berulang-ulang dan konsisten (Kurniawan, 2015).

Hasil penelitian di lapangan, penyusunan program tetap mengacu pada SKU (Syarat-syarat Kecakapan Umum) dan SKK (Syarat-syarat Kecakapan Khusus), serta visi dan misi sekolah yang dielaborasikan sehingga tersusun menjadi program ekstrakurikuler pramuka, yang terbagi ke dalam beberapa program jangka pendek, menengah, dan panjang.

Karakter siswa dapat dibentuk dengan melaksanakan program ektrakurikuler pramuka yang telah tersusun berdasarkan prinsip kebutuhan dan komitmen dari sekolah, keluarga, dan masyarakat. Oleh karena itu, butuh cara yang tepat dan memahami perkembangan siswa dalam rangka penguatan pendidikan karakter kepada anggota muda. Anggota pramuka golongan penggalang sekolah dasar berusia antara 11-12 tahun. Pada usia ini siswa masih membutuhkan bimbingan dari orang dewasa secara penuh. Cara yang tepat untuk mengajarkan siswa adalah dengan menggunakan pendekatan pedagogi. Pedagogi secara sederhana merupakan seni dalam mengajar. Hiryanto (2017) menjelaskan pedagogi sebagai teori pengajaran, yang dimana pendidik memiliki skill untuk memahami bahan ajar, mengenal karakteristik siswa dan merencanakan cara mengajarnya. Pendidik dalam hal ini adalah pembina memiliki peran sangat penting untuk memiliki kuaifikasi atau kompetensi khusus untuk mengajarkan pramuka pada siswa sekolah dasar. Berdasarkan penelitian Woro dan Marzuki (2016) dijelaskan faktor sikap, pengetahuan, dan pengalaman yang dimiliki pembina merupakan salah satu faktor pendukung pembentukan karakter pada anak. Oleh karena itu, untuk meningkatkan kualifikasi pembina, mereka diharuskan telah mengikuti pelatihan khusus untuk pembina, seperti Kursus Mahir Dasar (KMD), Kursus Mahir Lanjutan (KML), Kursus Pembina dasar (KPD), dan Kursus Pembina Lanjutan (KPL). Dari ketiga lokasi penelitian, pembina gugus depan telah mendapatkan pelatihan pada tingkat KPD sehingga segala bentuk perencanaan dan pelaksanaan kegiatan telah tersusun dengan baik.

Kemampuan pembina sebagai role model bagi siswa menjadi salah satu indikator penting keberhasilan program untuk membentuk karakter siswa. Sebelum pelaksanaan kegiatan, empat prinsip dasar kepramukaan menjadi hal penting yang harus dikuasai, yaitu: pertama, beriman dan bertakwa kepada Tuhan Yang Maha Esa;kedua, peduli terhadap bangsa, negara, manusia, dan isinya; ketiga, peduli diri sendiri; keempat, mentaati kode kehormatan pramuka. Empat prinsip dasar kepramukaan ini dijadikan sebagai norma hidup anggota yang harus dikembangkan melalui penghayatan dengan dibantu oleh pembina pramuka. Disisi lain, implementasi delapan metode kepramukaan dalam setiap kegiatan, memberikan dampak yang positif terhadap keaktifan dan motivasi siswauntuk mengikuti kegiatan ekstrakurikuler pramuka. Hasil yang sama juga dijelaskan oleh Nailiyah dkk. (2018) dalam penelitiannya bahwa metode kepramukaan sangat cocok untuk mendorong anak mengikuti kegiatan dan merasakan perubahan pada dirinya yang lebih baik. 
Metode kepramukaan mendorong untuk anak belajar secara interaktif dan progresif. Pertama, kode kehormatan pramuka yang tertuang dalam Tri Satya yang disebut sebagai janji dan Dasa Dharma Pramuka sebagai ketentuan moral yang harus dijunjung tinggi. Dengan metode ini, pembina dapat menguatkan karakter religus, disiplin, tanggung jawab, dan jujur. Karakter religius terlihat pada pengamalan janji Tri Satya yaitu menjalankan kewajiban terhadap Tuhan Yang Maha Esa. Jadi kegiataan keagamaan menjadi prioritas utama bagi anggota dengan menjalankan salat berjamaah, membaca yasin, dan tausiyah. Karakter disiplin juga dimunculkan dalam implementasi metode ini, bahwa setiap aturan yang telah ditetapkan bersama untuk dijalankan sebaik-baiknya. Sementara itu, karakter tanggung jawab muncul dalam pengamalan kode kehormatan pramuka, yang dimana janji yang telah diucapkan harus dipertanggungjawabkan dalam kehidupan sehari-hari. Sedangkan karakter jujur mencerminkan perilaku anggota yang dapat dipercaya, artinya janji yang telah diucapkan selaras dengan perbuatan anggota.

Kedua, kegiatan belajar sambil melakukan, penekanannya pada proses belajar yang bersifat praktis, yakni kegiatan yang dilakukan diawali dengan penyampaian materi dan dilanjutkan dengan praktik. Misalnya, pionering, penjelajahan, LKBB, semaphore, morse, sandi, dan pendirian tenda. Karakter yang dimunculkan adalah memiliki rasa ingin tahu, kreatif, dan kerja keras. Karakter rasa ingin tahu dilihat dari keaktifan anggota dalam bertanya dan berupaya untuk mendalami materi yang diajarkan. Kemudian menumbuhkan karakter kreatif kepada anggota pada saat mereka mampu menghasilkan karya baru dan memiliki solusi yang berbeda dengan apa yang dicontohkan oleh pembina, misalnya pembuatan pionering tiang bendera, anak sudah mampu menciptakan pionering yang lebih kreatif dibandingkan apa yng ditugaskan. Dan karakter kerja keras anggota muncul pada saat mereka berusaha mencari solusi dalam memecahkan sandi, morse, dan semaphore.

Ketiga, sistem berkelompok/regu, dengan tujuan memberikan anggota kesempatan belajar memimpin, dipimpin, dan memikul tanggung jawab. Selain itu, penggunaan sistem regu memudahkan penyelesaian tugas yang diberikan, dan memberikan kesempatan bagi anggota dalam regu untuk dapat belajar dengan anggota yang lebih bisa. Penerapan dari metode sistem berkelompok/ regu dapat menguatkan karakter demokratis, tanggung jawab, toleransi, dan komunikatif. Karakter demokratis muncul ketika anggota diamanahkan sebagai pemimpin regu, dia harus bertindak dan bersikap tidak memihak, serta tidak menang sendiri. Sedangkan karakter tanggung jawab dilihat dari kemampuan anak dalam mengkoordinir anggota dalam regunya. Sementara karakter toleransi terletak pada bagaimana anggota dalam regu dapat memahami perbedaaan pendapat, suku, dan agama yang berbeda dengan dirinya. Kemudian karakter komunikatif adalah anggota berupaya untuk memberikan kontribusi kepada kelompoknya, baik itu ide atau solusi, kreativitas, dan tindakan.

Keempat, kegiatan yang menarik dan menantang dengan melakukan kegiatan baru atau modern, sehingga kegiatan memiliki daya tarik dan siswa merasa tertantang untuk melakukannya. Melalui metode ini ada dapat menguatkan karakter kreatif, mandiri, rasa ingin tahu, cinta tanah air, dan kerja keras. Kegiatan pembina dalam menggunakan metode ini dengan cara memberikan kebebasan kepada siswa untuk mencoba hal-hal yang baru untuk mengasah potensi yang mereka miliki, seperti: bernyanyi, bermain peran (drama), mementaskan kesenian tari, pembacaan puisi, dan lain- 
lain. Melalui cara ini dapat menguatkan karakter kreatif, mandiri dan rasa ingin tahu siswa. Sementara dalam kegiatan lain, pembina pada saat latihan memberikan anggota untuk memainkan satu macam permainan tradisional nusantara, maka kegiatan ini dapat menguatkan karakter cinta tanah air. Dalam kegiatan lain yaitu melalui penjelajahan, siswa berusaha untuk memecahkan tugas atau soal-soal yang ada disetiap pos penjelajahan sehingga kegiatan ini dapat menguatkan karakter kerja keras

Kelima, kegiatan yang dilakukan di alam terbuka dengan melakukan perkemahan untuk dapat melatih anggota pramuka dapat bertahan hidup mandiri di alam terbuka secara sederhana. Karakter yang munculkan dalam metode ini yaitu karakter religius, peduli lingkungan, peduli sosial, mandiri, dan menghargai prestasi. Meskipun kegiatan dilakukan di alam terbuka kegiatan keagmaan tetap dijaga dan diperhatikan. Selain itu, menjaga kebersihan alam dan tidak merusak lingkungan dengan melakukan sapu bersih dan mengumpulkan sampah adalah bentuk penerapan dari karakter peduli lingkungan.

Karakter peduli sosial dilihat dari kegiatan "jika aku menjadi" memberikan dampak positif terhadap kepedulian anggota dengan lingkungan sosial disekitarnya. Setiap anggota harus dapat menyelesaikan tugas dengan baik, misalnya ketika diamanahkan oleh teman regunya untuk menjaga tenda dan memasak nasi atau lauk adalah wujud dari karakter mandiri. Sementara karakter menghargai prestasi dilihat dari kegiatan perkemahan biasanya dilaksanakan lomba dan memberikan reward kepada regu yang teraktif, ketika regu lain tidak mendapatkan penghargaan maka pembina mengarahkan dan mendorong anggota untuk terus melakukan yang terbaik dan menghargai prestasi yang telah didapatkan regu lain.
Keenam, pembina memiliki peran sebagai organisator dalam merencanakan, melaksanakan, mengontrol/mengawasi, bertanggungjawab, dan menilai setiap kegiatan. Pembina dapat memberikan dorongan, bimbingan, dan motivasi kepada anggota muda. Karakter yang muncul melalui metode ini yaitu jujur, disiplin, dan bertanggungjawab. Munculnya karakter jujur ketika siswa mendapatkan masalah dengan menyampaikan secara langsung apa yangdialami untuk diselesaikan secara bersama-sama. Peran pembina dalam menguatkan karakter disiplin dengan cara setiap siswa mendengarkan dan mematuhi larangan agar tidak menimbulkan hal-hal yang tidak diinginkan. Walaupun pembina sebagai organisator dalam gudep, akan tetapi pembina mengajarkan kepada anggota untuk tetap menjaga tanggung jawab secara bersama-sama.

Ketujuh, pemberian tanda kecakapan SKU dan SKK kepada nggota yang telah menyelesaikan tugas dan menguasai keterampilan-keterampilan tertentu. Hal ini bertujuan untuk meningkatkan semangat jiwa pramuka untuk dapat mengamalkan nilai-nilai kepramukaan dalam kehidupan sehari-hari. Pemberian penghargaan kepada anggota dapat menguatkan karakter menghargai prestasi, kerja keras, mandiri, dan disiplin.

Karakter menghargai prestasi dengan mendorong siswa untuk terus memberikan kontribusi kepada dirinya dan orang lain, serta menghargai kapasitas atau kemampuan yang dimiliki orang lain. Kegiatan pramuka diupayakan untuk dapat menciptakan suasana untuk menjunjung tinggi prestasi dengan menjalani ujian kenaikan tingkat dan golongan Sedangkan karakter mandiri dilihat dari bagaimana anggota untuk mencari dewan penguji SKU secara mandiri. Materi yang berkaitan dengan keagamaan maka anggota pramuka 
mencari guru agama, ujian berkaitan dengan nasionalisme anggota pramuka mencari guru kelas atau yang paham tentang nasionalisme. Jadi, siswa sudah diajarkan secara mandiri sejak dini untuk melatih mental dan kompetensinya. Kemudian karakter disiplin dimunculkan dari ketentuan yang ada dalam SKU dan SKK.

Kedelapan, menekankan pada sistem satuan terpisah antara putra dan putri. Hal ini dimaksudkan untuk memudahkan pembinaan anggota pramuka berdasarkan kebutuhan, karena antara kegiatan putra dan putri terdapat perbedaan yang signifikan dan masing-masing dibina berdasarkan sistem satuan terpisah, kecuali untuk perindukan siaga. Karakter yang dimunculkan melalui penerapan metode ini seperti karakter komunikatif, mandiri, dan tanggung jawab. Karakter komunikatif dilihat dari sikap dan tindakan anggota dalam mendorong dirinya untuk berkontribusi terhadap kelompok atau regunya. Selain itu, karakter mandiri dan tanggung jawab dimunculkan dari kemampuan masing-masing regu untuk dapat menyelesaikan tugas dan kewajibannya terhadap diri sendiri dan orang lain.

Implementasi delapan metode kepramukaan tidak dapat dilaksanakan secara satu persatuatau berdiri sendiri, karena metode tersebut merupakan satu rangkaian kegiatan, dan memungkinkan kedelapan dari metode kepramukaan dijalankan secara bersamaan atau serentak dan berkelanjutan. Melalui metode kepramukaan, siswa merasa antusias dan termotivasi untuk mengikuti seluruh rangkaian kegiatan kepramukaan. Oleh karena itu, metode kepramukaan sangat cocok diterapkan dalam setiap kegiatan kepramukaan untuk memberikan motivasi dan menguatkan pendidikan karakter siswa yang lebih baik.

Berdasarkan penjabaran di atas, dalam menguatkan pendidikan karakter pada siswa sekolah dasar dapat diformulasikan dalam bentuk model seperti yang disajikan pada Gambar 1.

Pada prinsipnya dalam menguatkan karakter siswa melalui penerapan metode kepramukaan harus ditanamkan secara konsisten, holistik, dan terintegrasi. Peran dari sekolah, keluarga, dan masyarakat

Gambar 1. Model dalam Menguatkan Pendidikan KarakterAnak melalui Kegiatan Kepramukaan

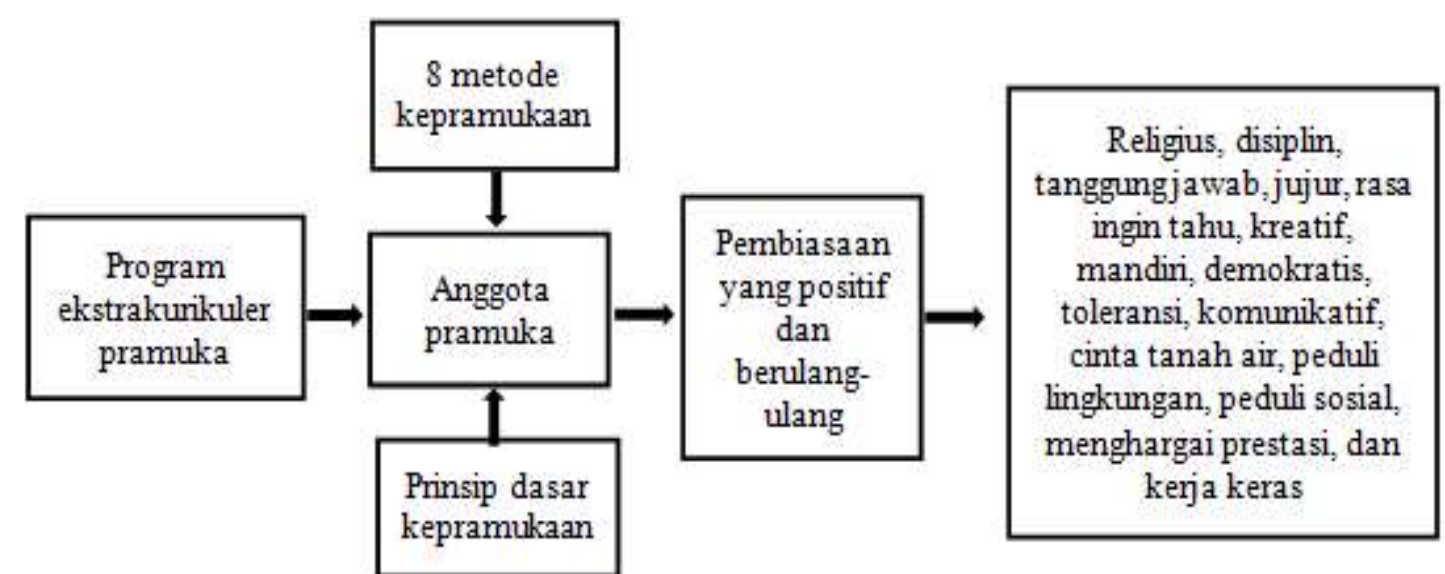


menjadi penting dalam membangun budaya lingkungan yang baik bagi siswa dengan pembiasaan yang positif dan berulangulang. Karena pendidikan karakter akan bepengaruh kepada siswa ketika dilakukan secara integral dan simultan antara ketiga peran, yakni sekolah, keluarga, dan masyarakat (Raharjo, 2010).

Menguatkan karakter siswa sekolah dasar bukanlah perkara mudah, akan tetapi karakter siswa bisa terjaga dengan baik apabila telah melewati beberapa tahapan, yaitu pengetahuan tentang karakter, diterapkan dalam kehidupan sehari-hari yang menjadi perilaku, dan perilaku tersebut dilakukan secara berulang-ulang secara konsisten sehingga menjadi sebuah kebiasaan (habit).

\section{SIMPULAN}

Berdasarkan hasil penelitian membuktikan bahwa implementasi delapan metode kepramukaan terdiri dari: mengamalkan kode kehormatan pramuka, memberikan bimbingan dan motivasi dari pembina, menyelenggarakan kegiatan secara berkelompok, menyelenggarakan kegiatan yang menarik dan menantang, melakukan aktivitas sambil belajar, menyelenggarakan kegiatan di alam terbuka, menerapkan sistem satuan terpisah, serta memberikan penghargaan tanda kecakapan (SKU dan SKK). Pelaksanaan metode kepramukaan berpotensi sebagai sarana yang tepat untuk menguatkan karakter siswa sekolah dasar. Karakter tersebut antara lain: sikap religius, disiplin, tanggung jawab, jujur, memiliki rasa ingin tahu, kreatif, mandiri, demokratis, toleransi, komunikatif, cinta tanah air, peduli lingkungan, peduli sosial, menghargai prestasi, dan kerja keras. Metode kepramukaan semestinya dapat dikembangkan dan diimplementasikan oleh guru dalam proses pembelajaran di sekolah dasar sebagai bentuk penguatan karakter siswa.

\section{DAFTAR PUSTAKA}

Afandi, R. (2011). Integrasi pendidikan karakter dalam pembelajaran IPS di sekolah dasar. Pedagogia: Jurnal Pendidikan, 1(1), 85-98. https://doi. org/10.21070/pedagogia.v1i1.32

Agustina, P. (2018). Karakteristik perilaku kepemimpinan kepala sekolah dan budaya sekolah di Sekolah Dasar. Pendididkan Karakter, VIII(2018), 206-219.

Ambarini, R. (2017). Pengembangan karakter dan kreativitas anak usia dini melalui total physical response warm up game. Jurnal Kependidikan, 1(1), 150-162. https://doi.org/http://dx.doi. org/10.21831/jk.vli1.9740.

Aeni, A. N. (2014). Pendidikan karakter untuk siswa SD dalam perspektif islam. Mimbar Sekolah Dasar, 1(1), 50-58. https://doi.org/10.1016/S00220248(02)02148-6.

Cahyo, E. D. (2017). Dekadensi moral yang terjadi pada siswa sekolah. EduHumaniora: Jurnal Pendidikan Dasar, 9(1), 16-26.

Dit. PSMP Kemdiknas. (2010). Pendidikan karakter terintegrasi dalampembelajaran di sekolah menengahpertama. Jakarta: Direktorat PSMP Kemdiknas.

Hiryanto. (2017). Pedagogi, andragogi dan heutagogi serta implikasinya dalam pemberdayaan masyarakat. Dinamika Pendidikan, 22(1), 65-71.

Irjanti, R., \& Setiawati, A. (2018). Pengaruh nilai-nilai karakter terhadap prestasi belajar di SDIT Salman Al-Farisi. Jurnal Pendidikan Karakter, 8(I), 40-50.

Isdaryanti, B., Rachman, M., Sukestiyarno, Y. L., Florentinus, T. S., \& Widodo, W. (2018). Teachers' performance in science learning management integrated with character education. 
Jurnal Pendidikan IPA Indonesia, 7(1), 9-15. https://doi.org/10.15294/ jpii.v7il.12887.

Kurniawan, M. I.(2015). Tripusat pendidikan sebagai sarana pendidikan karakter anak sekolah dasar. Pedagogia: Jurnal Pendidikan, 4(1), 41. https://doi. org/10.21070/pedagogia.v4i1.71

Marzuki, \& Hapsari, L. (2015). Pembentukan karakter siswa melalui kegiatan kepramukaan di MAN 1 Yogyakarta. Jurnal Pendidikan Karakter, 5(2), 142-156.

Miles, B. M., \& Huberman, M. (1992). Analisis data kualitatif buku sumber tentang metode-metode baru. Jakarta: UI Press.

Murdiono, M., Miftahuddin, \& Kuncorowati, P. W. (2017). The education of the natio-nal character of pancasila in secondary school based on pesantren. Cakrawala Pendidikan, 10(3), 423-434.

Nailiyah, R. D., Dayati, U., \& Desyanty, E. S. (2018). Implementasi metode kepramukaan (studi kasus pembinaan pramuka penggalang berprestasi di Kwarcab, Kabupaten Malang). Pendidikan: Teori, Penelitian, dan Pengembangan, 3(4), 480-485.

Menteri Pendidikan dan Kebudayaan. (2014). Permendidikbud RI Nomor 63 Tahun 2014 tentang Pendidikan Kepramukaan. Jakarta: Kemendikbud.

Qoyyimah, U. (2016). Inculcating character education through EFL teaching in Indonesian state schools. Pedagogies, 11(2), 109-126. https://doi.org/10.108 0/1554480X.2016.1165618.

Raharjo, S. B. (2010). Pendidikan karakter sebagai upaya menciptakan akhlak mulia. Pendidikan dan Kebudayaan, 16(3), 229-238.
Solihati, N., Hikmat, A., Rahman J., A., \& Hidayatullah, S. (2019). Nilai pendidikan karakter dalam permainan rakyat di Lereng Gunung Merapi. Jurnal Kependidikan, 3(1), 28-42. https://doi.org/http://dx.doi. org/10.21831/jk.v3i1.22327.

Sukoyo, J. (2017). Efektivitas lagu-lagu berbahasa jawa untuk menanamkan nilai-nilai karakter siswa. Jurnal Kependidikan, 1(2), 163-173.

Suratmi, N., \& Munhaji, U. (2015). Model pembelajaran "unfold circles" untuk membangun pendidikan karakter dan potensi anak di Lembaga PAUD. Pendidikan dan Kebudayaan, 21(2), 183-192.

Presiden Republik Indonesia. (2010). Undang-Undang Nomor 12 Tahun 2010 Tentang Gerakan Pramuka. Jakarta.

Wijayanti, D. (2018). Character education designed by Ki Hadjar Dewantara. EduHumaniora: Jurnal Pendidikan Dasar, 10(2), 85-91.

Woro, S., \& Marzuki, M. (2016). Peran kegiatan ekstrakurikuler pramuka dalam pembentukan karakter tanggung jawab peserta didik di SMP Negeri 2 Windusari Magelang. Jurnal Pendidikan Karakter, 6(1), 59-73. https://doi.org/10.21831/jpk. v0i1.10733.

Wulandari, T., Wijayanti, A. T., \& Saliman. (2019). Pendidikan karakter dalam keluarga melalui pola asuh orang tua. Jurnal Kependidikan, 3(1), 129142. https://doi.org/http://dx.doi. org/10.21831/jk.v3i1.22392.

Yatmiko, F., Banowati, E., \& Suhandini, P. (2015). Implementasi pendidikan karakter anak berkebutuhan khusus. Journal of Primary Education, 4(2), 77-84. 